\title{
Purification and Characterization of 50 kDa Extracellular Metalloprotease from Serratia sp. ZF03
}

\author{
Navvabeh Salarizadeh ${ }^{1}$, Sadegh Hasannia ${ }^{2,3,{ }^{*}, \text { Kambiz Akbari Noghabi }}{ }^{3}$, Reza Hassan Sajedi ${ }^{2}$ \\ ${ }^{1}$ Department of Biology, Faculty of Sciences, University of Guilan, Rasht, I.R. IRAN \\ ${ }^{2}$ Department of Biochemistry, Faculty of Biological Sciences, Tarbiat Modares University, Tehran, I.R. IRAN \\ ${ }^{3}$ National Institute of Genetic Engineering and Biotechnology (NIGEB), Tehran, I.R. IRAN \\ *Corresponding author: Sadegh Hasannia, Faculty of Biological Sciences, Tarbiat Modares University, P.O. Box 14115-111, \\ Tehran, I.R. IRAN. Tel/Fax: +98-21-82884717, E-mail: hasannia@modares.ac.ir
}

Received: November 16, 2013; Revised: July 03, 2014

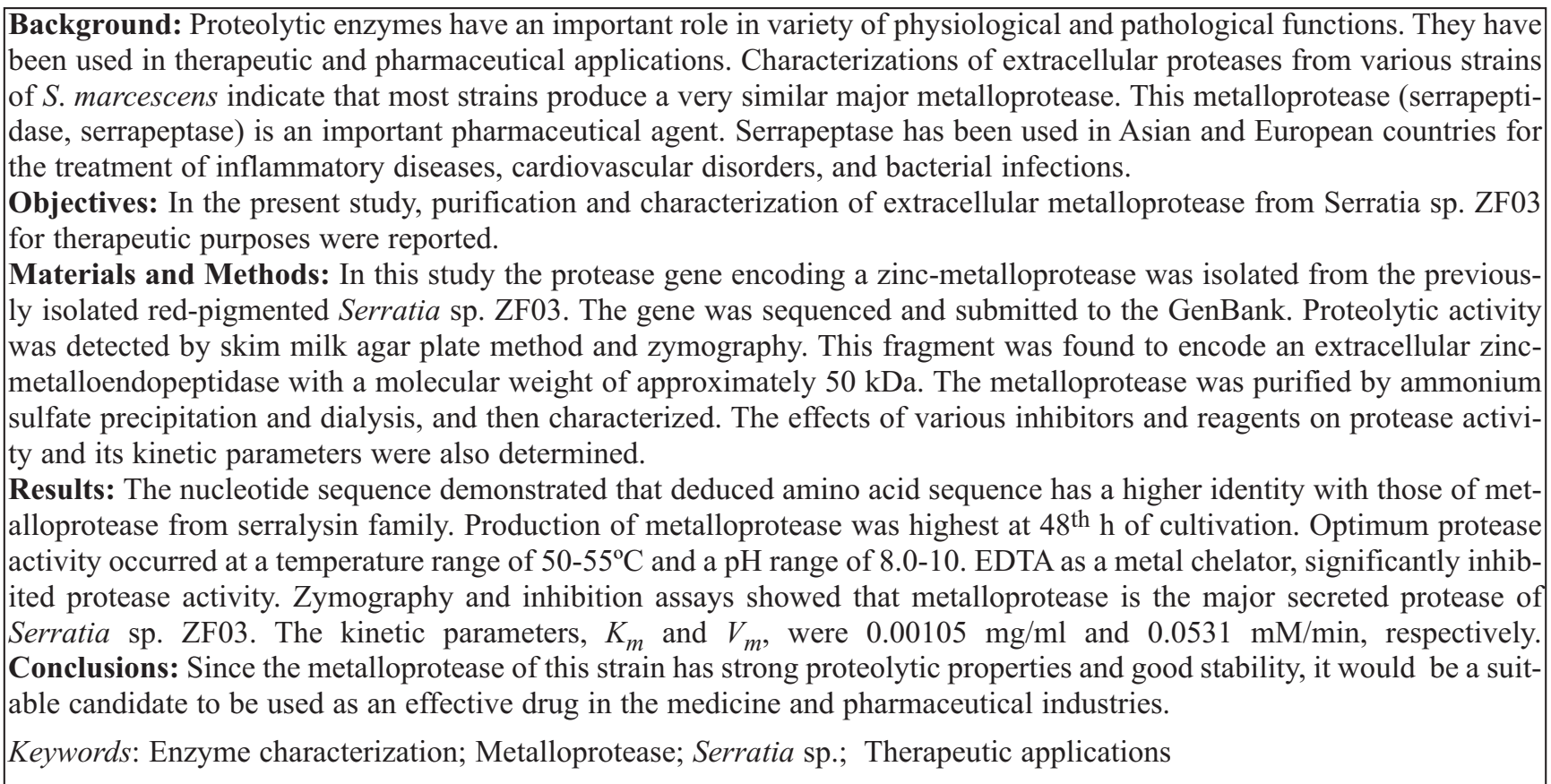

\section{Background}

Inflammatory response, a standard clinical condition, is an important defense mechanism that protects the tissues from invasion by organisms and damaged cells. A variety of enzymes have been used extensively in the management of protein deficiencies and therapeutic applications. Proteolytic enzymes can be administered with non-steroidal anti-inflammatory drugs. Proteolytic enzymes such as chymotrypsin, trypsin and serratiopeptidase play an important role in the inflammatory processes (1). Proteases are found in living organisms including plants, animals, and microbes. In fact, microbe-derived proteolytic enzymes are extracted from or synthesized by bacterial and fungal sources such as streptokinase, a proteolytic enzyme preparation from $\beta$-hemolytic streptococci, brinase from Aspergillus oryzae, Sutilain, a proteolytic enzyme isolated from Bacillus subtilis, arazyme from Serratia proteamaculans, and bacterial toxins like tentoxilysin (tetanus neurotoxin), botulinum neurotoxin and anthrax toxin lethal factor (2-7). Microbial proteases can be divided into different classes, according to activity under acidic, neutral and alkaline environments, chemical characteris- 
tic of the catalytic site (serine, threonine, cysteine, aspartic and metallo-peptidases) and mechanism of action. Alkaline proteases are specified as those proteases which are active in a $\mathrm{pH}$ range from neutral to alkaline $(8,9)$. Metalloproteases (E.C. 3. 4. 24.) represent the largest class of hydrolases which usually have a catalytic zinc ion in the active site. According to importance and the diversity of metalloproteases, these zinc-dependent enzymes are important targets for biomedical applications (10). Serratia marcescens is a Gramnegative bacterium of the family Enterobacteriaceae that secretes a variety of degradative enzymes, such as proteases (serine and thiol proteases, and metalloproteases), lipases, chitinases, hemolysin, and nucleases $(11,12)$. Extracellular zinc metalloendopeptidase, secreted by various Serratia strains, specially $S$. marcescens, that has been purified and characterized (11-16). In ten clinical isolates of $S$. marcescens, a $1.5 \mathrm{~K}$ bp DNA fragment was amplified, which represented the metalloprotease gene that encoded this protease (11). Serrapeptase (also known as serrapeptidase, serratiopeptidase and serratia peptidase) is a metalloprotease that has been purified and characterized from the Serratia. sp E-15 strain which was isolated from the gut of a larval silkworm $(7,12)$. This enzyme dissolved the rigid proteins of cocoon and allowed the moth to come out (17). It is an effective drug for the treatment of breast engorgement (18) and relieves swelling and pain following maxillary sinus antrostomy (11). Serrapeptase is also used to degrade atherosclerotic plaque and fibrin on the inside of arteries $(19,20)$. In general, this major metalloprotease has been identified in various strains of Serratia (11-16) and because of its economic significance, particularly as an anti-inflammatory agent (19), this enzyme is currently being produced commercially and under trade names: Serrapeptase, Aniflazym, Danzen, Serrazyme, Serracel and SerraGold is sold $(16,18)$. Serrapeptase has been permitted to enter as a standard drug in Germany and other European countries for therapeutic consumptions (17). This protease has been used as mucoactive and antiinflammatory treatment in Japan for 30 years (21). The Serratia marcescens metalloprotease is a member of the serralysin family of proteolytic enzymes, which is a group of metalloproteases with molecular weights of approximately $50 \mathrm{kDa}$, and is produced by a variety of species, such as Erwinia chrysanthemi, yersinia pestis, Pseudomonas aeruginosa and Yersinia ruckeri. The serralysin family belongs to the metzincin clan of metalloproteinases (mainly clan (MA)(M) according to the MEROPS database) (22).

\section{Objectives}

Because of the therapeutic and commercial significance of metalloproteases, this study attempted to investigate the extracellular metalloprotease produced by the red-pigmented serratia sp. ZF03, a strain previously isolated from the hot-springs of high background radiation areas (HBRAs) in Ramsar, Iran (23). The metalloprotease gene was isolated and sequenced, and the extracellular enzyme was subsequently purified and characterized.

\section{Materials and Methods}

\subsection{Bacterial Strain, Cultures, Chemicals and Reagents}

The bacterium used, Serratia sp. ZF03, was previously isolated from the hot-springs of high background radiation areas in Ramsar, Mazandaran province of Iran (23). Ethylenediaminetetraacetic acid (EDTA), phenylmethylsulfonyl fluoride (PMSF), and iodoacetamide were purchased from Sigma Aldrich (USA). Ammonium sulfate, casein, tryptone, yeast extract, skim milk, glycine, acrylamide, bisacrylamide, ammonium persulfate and all other chemicals were obtained from Merck (Germany). The PCR Master Mix (buffer, Taq DNA polymerase, $\mathrm{MgCl}_{2}$ ) was purchased from TaKaRa (Kyoto, Japan).

\subsection{Culture Conditions}

In order to detect protease production and activity, bacterial culture samples were used to inoculate skim milk agar plates, which were then incubated at $30^{\circ} \mathrm{C}$ for $24 \mathrm{~h}$. Proteolytic activity was exhibited by a clear zone around or under the colony. A single colony from the $S$. marcescens plate culture was used to inoculate LB broth containing $0.5 \%(\mathrm{w} / \mathrm{v})$ glucose. Cultivation was carried out at $30^{\circ} \mathrm{C}$ for $12 \mathrm{~h}$ in a rotating shaker, with shaking at $250 \mathrm{rpm}$. Subsequently, $0.1 \mathrm{ml}$ of the preculture was inoculated into a $1000 \mathrm{ml}$ baffled erlenmeyer flask containing $200 \mathrm{~mL}$ of culture 
medium, which consisted of the following: tryptone $8 \mathrm{~g}$, yeast extract $4 \mathrm{~g}$, glycine $0.02 \mathrm{~g}, \mathrm{NaCl} 1$ g, skim milk $1 \%(\mathrm{w} / \mathrm{v})$ and $0.5 \%(\mathrm{w} / \mathrm{v})$ glucose. Skim milk and glucose induced the metalloprotease production (16). Cultures were incubated under the above mentioned conditions for $96 \mathrm{~h}$. Samples of culture supernatant were removed for subsequent analysis at $6 \mathrm{~h}$ intervals.

\subsection{Amplification of the Metalloprotease Gene by PCR}

The genomic DNA of Serratia sp. ZF03 was extracted by the HiYield ${ }^{\mathrm{TM}}$ Genomic DNA Mini Kit (Real Biotech Corporation, Taiwan), according to manufacturer's instructions forward: 5'ATG CAA TCT ACT AAA AAG GCA ATT G-3' and reverse: 5'-TTA CAC GAT AAA GTC AGT G-3' primers designed according to the metalloprotease gene of Serratia. sp. E-15 (X04127.1). Amplification of DNA was carried out using the following PCR program: pre-denaturation at $95^{\circ} \mathrm{C}$ for $5 \mathrm{~min}$, denaturing at $95^{\circ} \mathrm{C}$ for $30 \mathrm{~s}$, annealing at $57.8^{\circ} \mathrm{C}$ for $45 \mathrm{~s}$, extension at $72^{\circ} \mathrm{C}$ for $55 \mathrm{~s}(30$ cycles) and a final polymerization step at $72^{\circ} \mathrm{C}$ for $10 \mathrm{~min}$. After amplification, reaction mixture was loaded onto $1 \%$ agarose gel. The amplified DNA fragment was then extracted from the agarose gel and sequenced using Sanger's method (Cinagene, Iran). A Sequence homology search was performed using the NCBI BLAST server (http://www.ncbi.nlm.nih.gov/BLAST) and ClustalW2-multiple sequence alignment program.

\subsection{Protease Purification}

For purification of the protease, bacterial culture was centrifuged at $10,000 \times \mathrm{g}$ for $20 \mathrm{~min}$ at $4^{\circ} \mathrm{C}$. The resulting supernatant was precipitated with ammonium sulfate at different saturation levels $(50 \%, 60 \%, 67 \%, 70 \%$ and $80 \%)$. The most appropriate level of saturation for precipitation of the protease was $67 \%$. Ammonium sulfate (at $67 \%$ saturation level) was added slowly to the culture supernatant with stirring at $4^{\circ} \mathrm{C}$. After $1 \mathrm{~h}$, the precipitate was collected by centrifugation at $13,000 \mathrm{~g}$ for $20 \mathrm{~min}$. The resulting pellet was then dissolved in a minimum of $20 \mathrm{mM}$ Tris buffer $(\mathrm{pH}$ 8.0) and dialyzed against the same buffer for $16 \mathrm{~h}$ with three buffer changes. Protein concentration was determined by the method of Bradford (24) with bovine serum albumin (BSA) $(1 \mathrm{mg} / \mathrm{ml})$ as the standard. The protein concentration was esti- mated by measuring the absorbance at $595 \mathrm{~nm}$ using a T90 UV-Visible spectrophotometer (Varian Cary Eclipse, Australia).

\subsection{Polyacrylamide Gel Electrophoresis and Zymogram Analysis}

SDS-polyacrylamide gel electrophoresis was carried out according to the method of Laemmli with some modifications (25), using a $12 \%$ polyacrylamide separating gel and a 5\% stacking gel to analyze the protein samples and estimate molecular weight of the protease. Following electrophoresis, the gel was stained with Coomassie Brilliant Blue R-250 and silver nitrate. Detection of protease was also achieved by zymography in the presence and absence of inhibitors such as EDTA, PMSF and iodoacetamide, using gelatin as substrate. Sodium dodecyl sulfate polyacrylamide gels $(12 \%)$ were co-polymerized with $0.01 \%$ $(\mathrm{w} / \mathrm{v})$ gelatin. Samples were dissolved in nonreducing SDS-loading buffer without heating. Following electrophoresis, the gels were washed (incubated for $1 \mathrm{~h}$ at room temperature on a rotating shaker to remove the SDS and renature the proteinases) with $2.5 \%$ Triton-X100 in $50 \mathrm{mM}$ Tris ( $\mathrm{pH} 7.4$ ), $5 \mathrm{mM} \mathrm{CaCl}_{2}$, and $1 \mu \mathrm{M} \mathrm{ZnCl}_{2}$. The buffer was then decanted and the gels were washed by deionized water and incubated for 10 min at $37^{\circ} \mathrm{C}$ with developing buffer $(50 \mathrm{mM}$ Tris (pH 8), $5 \mathrm{mM} \mathrm{CaCl}, 1 \alpha \mathrm{M} \mathrm{ZnCl}_{2}$ (optional $0.01 \%$ sodium azide)), and subsequently stained with Coomassie Brilliant Blue G-250. Zones of proteolysis were detected by destaining.

\subsection{Protease Assay}

In order to determine proteolytic activity, casein was used at a final concentration of $1.0 \%$ $(\mathrm{w} / \mathrm{v})$ in a $0.5 \mathrm{ml}$ assay reaction mixture containing $20 \mathrm{mM}$ Tris- $\mathrm{HCl}$ buffer, $10 \mathrm{mM} \mathrm{CaCl},(\mathrm{pH}$ $8.0)$, and appropriate amount $(20 \mu \mathrm{L})$ of the enzyme. The reaction mixture was incubated for $10 \mathrm{~min}$ at $37^{\circ} \mathrm{C}$ and terminated by adding $0.5 \mathrm{ml}$ of $10 \%(\mathrm{w} / \mathrm{v})$ trichloroacetic acid (TCA) on ice. After $20 \mathrm{~min}$, mixture was centrifuged at 18000 $\times \mathrm{g}$ for $10 \mathrm{~min}$, and the absorbance of the supernatant was measured at $280 \mathrm{~nm}$.

\subsection{Enzyme Characterizations}

For determination of optimum temperature, the enzyme samples were incubated at temperatures between $30-65^{\circ} \mathrm{C}$ for $10 \mathrm{~min}$, using the same stan- 
dard assay conditions mentioned above. Thermostability of the enzyme was assessed in 20 $\mathrm{mM}$ Tris- $\mathrm{HCl}, \mathrm{pH} 8.0$ by incubating the purified protein sample at $40^{\circ} \mathrm{C}$ and $50^{\circ} \mathrm{C}$ for $60 \mathrm{~min}$ for different time intervals. Enzyme activity was then determined at $37^{\circ} \mathrm{C}$ as described above. The $\mathrm{pH}$ profile of enzyme was determined in different $\mathrm{pH}$ values, at $37^{\circ} \mathrm{C}$ for $10 \mathrm{~min}$. The reaction mixture consisted of $1 \%(\mathrm{w} / \mathrm{v})$ casein in Britton-Robison universal buffer $\left(0.04 \mathrm{M} \mathrm{H}_{3} \mathrm{PO}_{4}, 0.04 \mathrm{M} \mathrm{H}_{3} \mathrm{BO}_{3}\right.$, $0.04 \mathrm{M} \mathrm{CH}_{3} \mathrm{COOH}$ ) (26). The activity was determined under standard assay method. Protease enzyme samples were pre-incubated with reagents and inhibitors for $10 \mathrm{~min}$ at room temperature, the vials were then transferred to a $37^{\circ} \mathrm{C}$ water bath and substrate was added. Residual activity was measured under the standard assay conditions. The effect of different metal ions on protease activity was also investigated. Enzyme samples were pre-incubated with different metal ions. Assays were carried out as mentioned above, and the percentage residual activity of the enzyme, in the presence of each metal ion, was subsequently determined.

\subsection{Determination of Kinetic Parameters}

The enzyme's kinetic parameters, $K_{m}$ and $V_{\max }$, were determined using different casein concentrations as the substrate under assay conditions. Metalloprotease indicated a Michaelis-Menten type kinetics when hydrolyzing soluble casein. $K_{m}$ and $V_{\max }$ values were obtained by LineweaverBurk plot.

\section{Results}

\subsection{Detection of Protease Activity}

The production of protease by the Serratia sp. ZF03 was investigated. The results of the skim milk agar method showed large clear zones around the colonies after $24 \mathrm{~h}$ of incubation (Figure 1). In addition, protease activity was also evaluated in the presence of inhibitors such as PMSF, EDTA, iodoacetamide using gelatin zymography. Proteolytic activity was inhibited completely by EDTA, a known inhibitor of metalloproteases, and partially inhibited in presence of PMSF. Iodoacetamide didn't show any inhibitory effects. Zymogram analysis confirmed that the major secreted protease was metalloprotease. (Figure 2).

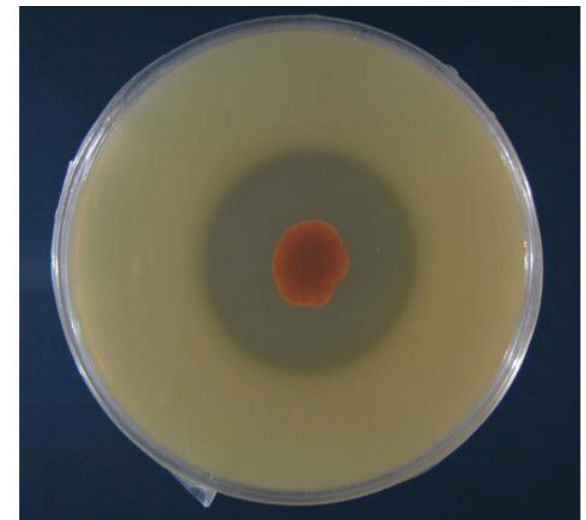

Figure 1. Proteolytic activity as detected by the skim milk agar plate method

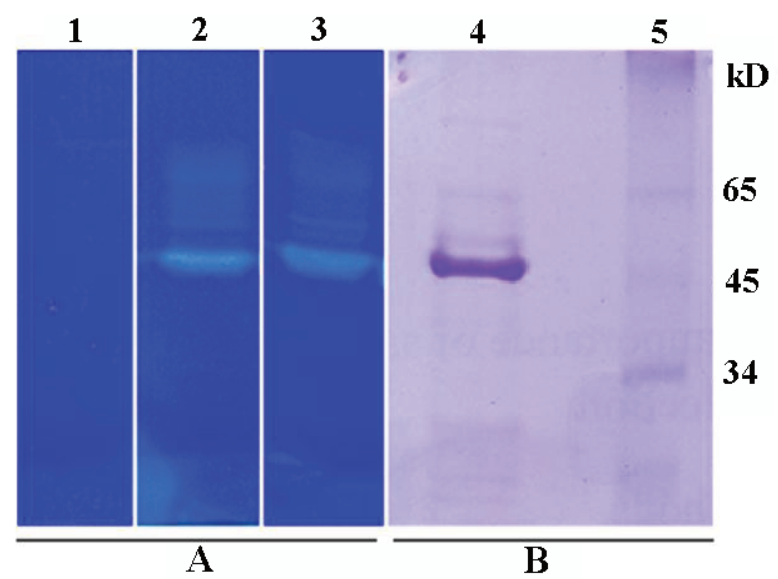

Figure 2. Gelatin-zymography of protease in the presence and absence of inhibitors. Zymogram gel was stained with Coomassie Brilliant Blue G-250. (A) Lane1, protease activity in the presence of EDTA; Lane 2, PMSF and Lane 3, in the absence of inhibitors. (B) SDS-PAGE; gel stained with Coomassie Brilliant Blue R-250. Lane 4, purified protease and lane 5, molecular weight marker

4.2. Amplification of the Metalloprotease Gene and Sequencing Analysis

Following extraction of the whole genome of Serratia. sp. ZF03, PCR was performed using primers designed according to the metalloprotease gene of Serratia. sp. E-15. The amplified DNA fragment was about $1.5 \mathrm{~kb}$ in size. The gene was sequenced and submitted to the GenBank, (http://www.ncbi.nlm.nih.gov/), under the accession number JX412231. Sequence homology search of the gene showed $97 \%$ and $96 \%$ maximum identity with that of the metalloprotease 
gene of Serratia marcescens strain SM6 and Serratia (sp. E-15) gene (27). The deduced amino acid sequence of the gene showed 99\% identity with the serratiopeptidase from Serratia sp. E-15 and $S$. marcescens metalloprotease.

\subsection{Time Course of Metalloprotease Production}

In order to determine the time course of protease production during bacterial growth, the proteolytic enzyme activity of culture supernatants was measured throughout the growth period, up to the $96^{\text {th }} \mathrm{h}$. The production of total protease was observed at $12^{\text {th }} \mathrm{h}$ of growth time, and reached a plateau at the end of the exponential phase. Maximum metalloprotease production was detected at the $48^{\text {th }} \mathrm{h}$ of growth (Figure 3 ).

\subsection{Metalloprotease Purification}

In order to purify the enzyme, the metalloprotease produced by $S$. marcescens $\mathrm{ZF03}$ was precipitated by ammonium sulfate at the $67 \%$ saturation level. The precipitated sample was then dissolved in a minimum of Tris buffer $(\mathrm{pH} \mathrm{8.0)}$ and dialyzed. The protease exhibited good purity after this step. The purified enzyme was shown to have a molecular weight of approximately $50 \mathrm{kDa}$ on SDS-PAGE (Figure 4).

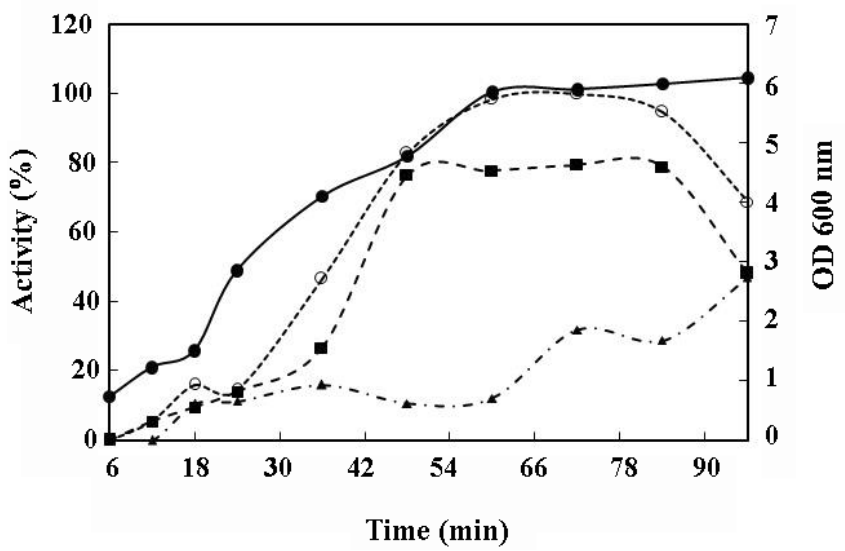

Figure 3. The time course of protease production: Total protease $(\mathrm{O})$, metalloprotease $(\boldsymbol{\bullet})$, serine protease $(\boldsymbol{\Delta})$ and cell growth $(\mathbf{0})$. The protease activity of culture supernatants was measured throughout the growth period, up to the $96^{\text {th }} \mathrm{h}$. In order to determine the type of secreted proteases by the strain, protease activity was also measured in the presence of protease different inhibitors. The growth of Serratia sp. ZF03 was also measured by cultivation time at $600 \mathrm{~nm}$

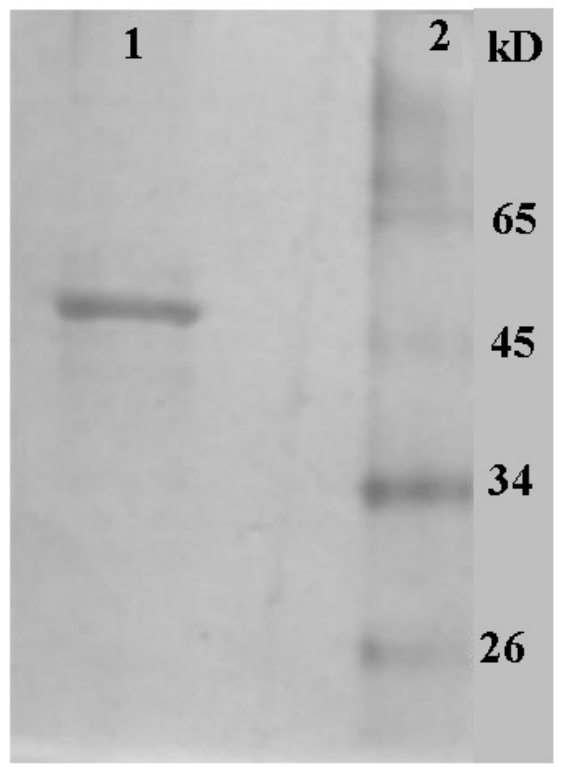

Figure 4. SDS-PAGE analysis of the purified enzyme. Lane 1 , purified metalloprotease and lane 2, molecular weight markers. Protein band appeared by silver staining

\subsection{Biochemical Characterization}

The optimum temperature for metalloprotease activity was observed in the range of $50-55^{\circ} \mathrm{C}$ (Figure 5A). Optimum metalloprotease activity was also observed at the $\mathrm{pH}$ range of $8-10$ with a maximum activity at $\mathrm{pH}$ 9.0. The effect of metal ions, various reagents and inhibitors on protease activity are also shown in Tables 1 and 2. The use of inhibitors showed that EDTA inhibited significant protease activity compared to PMSF and iodoacetamide (Table 2). Also 1,10 phenanthroline, another inhibitor of metalloprotease, decreased enzyme activity. Iodoacetamide had not only inhibitory effect but also increased the proteolytic activity. Also, iodoacetamide didn't show any inhibition effect on zymogram gel. The activity of the protease was also found to increase in the presence of $\mathrm{Co}^{2+}, \mathrm{Na}^{+}$and the reagents such as DMSO. The thermostability results showed that the enzyme was stable and active at $40^{\circ} \mathrm{C}$, Protease retained approximately $96 \%$ of its activity after $60 \mathrm{~min}$ at $40^{\circ} \mathrm{C}$, whereas $24 \%$ of enzyme activity was conserved, when incubated at $50^{\circ} \mathrm{C}$ after $60 \mathrm{~min}$ (Figure 5C). The kinetic parameters, $K_{m}$ and $V_{\max }$, as determined by the LineweaverBurk plot were $0.00105 \mathrm{mg} / \mathrm{ml}$ and 0.0531 $\mathrm{mM} / \mathrm{min}$, respectively (Figure 6). 
Table 1. The effect of metal ions on protease activity. All the metal ions were added as chloride salts $(2 \mathrm{mM})$

\begin{tabular}{lc}
\hline Metal ions & Residual activity (\%) \\
\hline Control & 100 \\
$\mathrm{Mg}^{2+}$ & 68.53 \\
$\mathrm{Na}^{+}$ & 103.462 \\
$\mathrm{~K}^{+}$ & 97.83 \\
$\mathrm{Ca}^{2+}$ & 60.72 \\
$\mathrm{Al}^{3+}$ & 47.05 \\
$\mathrm{Ba}^{2+}$ & 97.6 \\
$\mathrm{Zn}^{2+}$ & 32.195 \\
$\mathrm{Fe}^{2+}$ & 77.07 \\
$\mathrm{Fe}^{3+}$ & 89.76 \\
$\mathrm{Mn}^{2+}$ & 85.27 \\
$\mathrm{Co}^{2+}$ & 108.20 \\
\hline
\end{tabular}

Table 2. The effect of inhibitors and reagents on protease activity

\begin{tabular}{lcc}
\hline Inhibitors/reagents & Concentration & $\begin{array}{c}\text { Residual activity } \\
\text { (\%) }\end{array}$ \\
\hline Control & - & 100 \\
SDS & $2 \%(\mathrm{w} / \mathrm{v})$ & 53 \\
SDS & $5 \%(\mathrm{w} / \mathrm{v})$ & 50 \\
DMSO & $2 \%(\mathrm{v} / \mathrm{v})$ & 145 \\
DMSO & $5 \%(\mathrm{v} / \mathrm{v})$ & 100 \\
Triton & $5 \%(\mathrm{v} / \mathrm{v})$ & 81 \\
Tween80 & $2 \%(\mathrm{v} / \mathrm{v})$ & 57 \\
Ethanol & $2 \%(\mathrm{v} / \mathrm{v})$ & 30 \\
EDTA & $5 \mathrm{mM}$ & 60 \\
EDTA & $10 \mathrm{mM}$ & 13 \\
1,10 phenanthroline & $2 \mathrm{mM}$ & 54 \\
lodoacetamide & $0.5 \mathrm{mM}$ & 115 \\
lodoacetamide & $0.1 \mathrm{mM}$ & 147 \\
PMSF & $2 \mathrm{mM}$ & 88 \\
PMSF & $1 \mathrm{mM}$ & 93 \\
\hline
\end{tabular}

\section{Discussion}

Proteolytic enzymes are one of the most prominent groups of industrial enzymes that account for about $60 \%$ of the enzyme economics and they are used in variety of industries such as pharmaceutical industry and medicine, detergents, leather and food industry (28). Proteolytic enzymes have been used widely in management of enzyme deficiencies and therapeutic applications. These enzymes
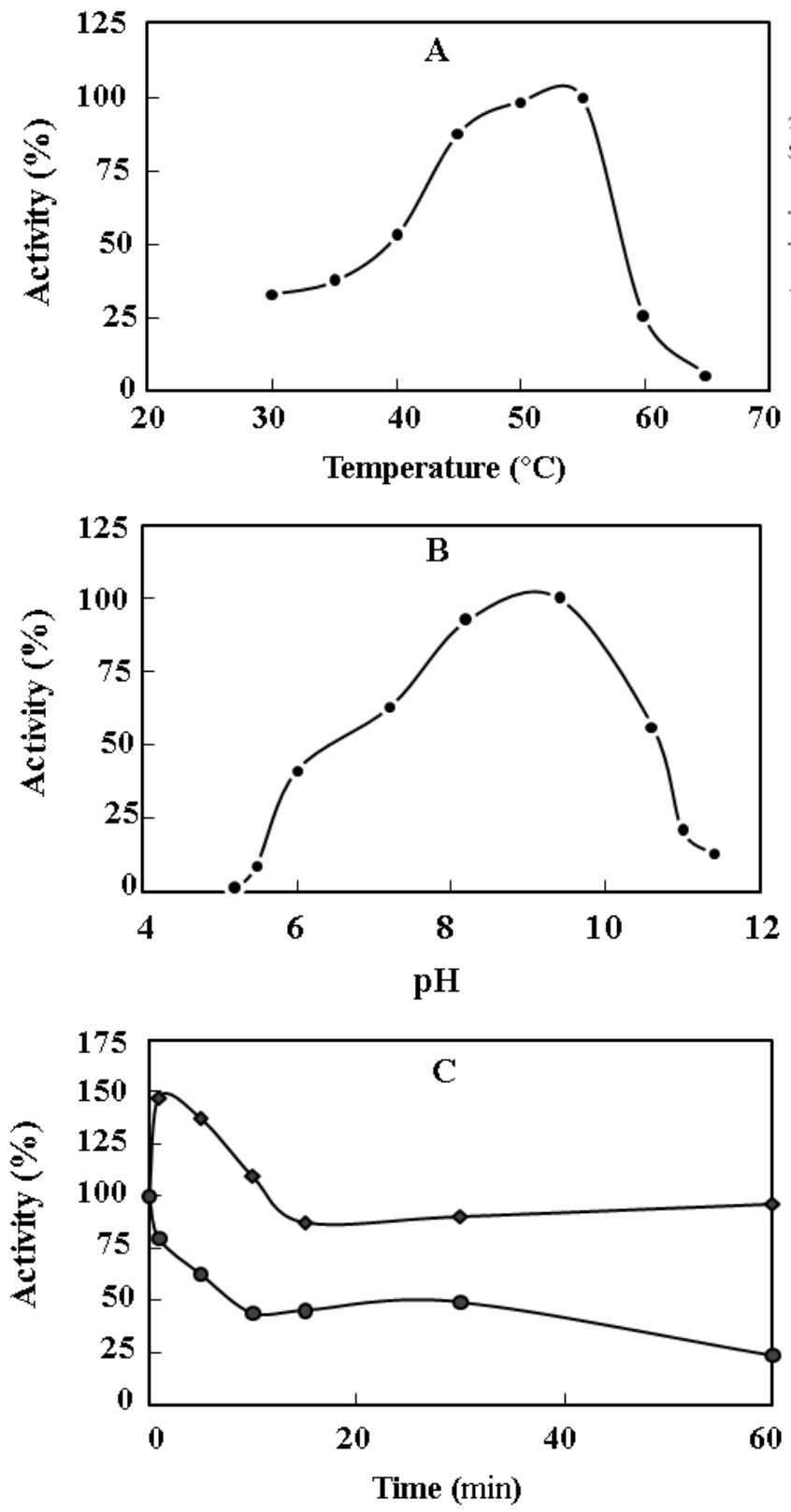

Figure 5. Effect of temperature (A) and $\mathrm{pH}(\mathrm{B})$ on protease activity. (C) Irreversible thermoinactivation of metalloprotease from Serratia. sp. ZF03 at $40^{\circ} \mathrm{C}(\bullet)$ and $50^{\circ} \mathrm{C}(\bullet)$

are co-administered with non-steroidal antiinflammatory agents (2). One of these enzymes is strain-dependent metalloprotease which is secreted by various $S$. marcescens strains (11-16). In this research, the production of protease by the Serratia sp. ZF03 (native to Iran) was investigated. First, in order to identify the metalloprotease gene, the DNA fragment (1.5 kbp in size) was isolated from genome of serratia according to primers designed based on the metalloprotease 


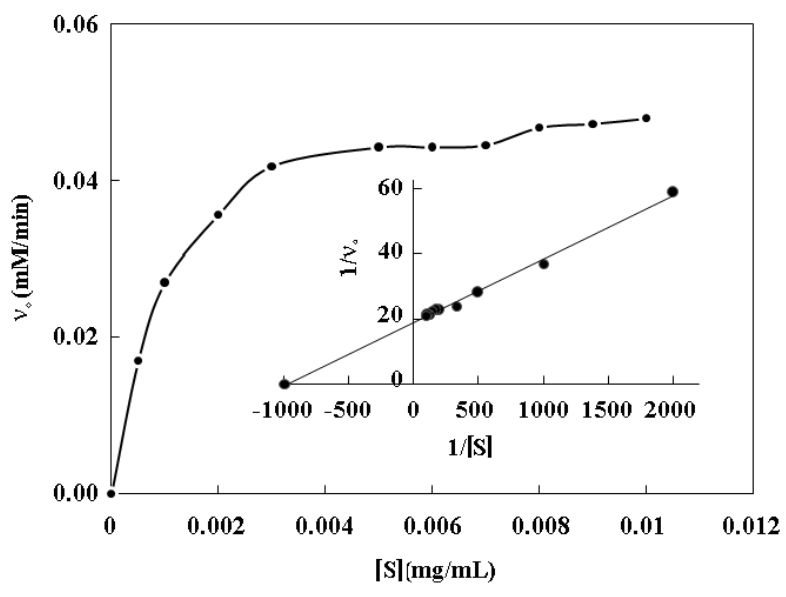

Figure 6. Michaelis-Menten Curve of Serratia. sp. ZF03 metalloprotease. $K_{m}$ and $V_{\max }$ values were determined by Lineweaver-Burk plot (inset)

gene of Serratia sp. E-15. The molecular weight of the encoded protein, as revealed by SDSPAGE, was approximately $50 \mathrm{kDa}$. The results of sequence homology confirmed high identity of this metalloprotease with $S$. marcescens metalloprotease. For determining the type of secreted proteases by the strain, protease activity was also measured in the presence of protease inhibitors such as EDTA, inhibitor of metalloproteases, PMSF (inhibitor of serine-proteases) and iodoacetamide (inhibitor of cysteine proteases). Serineproteases are inhibited by PMSF at concentrations of 0.1-1 mM. Results showed that total protease activity was observed at $12^{\text {th }} \mathrm{h}$ of growth time, had increased exponentially during cell growth and reached to stationary $\mathrm{p}$ at $60 \mathrm{~h}$ of cultivation time (Figure 3). Because of the low cell growth production the protease production was very low in the first time of cultivation. As total protease, metalloprotease activity increased and remained constant between the $48^{\text {th }}-78^{\text {th }} \mathrm{h}$ of growth. The protease (total and metallo- protease) production decreased in the stationary phase of cell growth after $84 \mathrm{~h}$, but an increase in activity of serine-protease was observed. This loss of activity might be due to the protease autolysis. The serine-proteases, significantly was not detected throughout the growth period. In fact, maximum metalloprotease production was detected at the $48^{\text {th }} \mathrm{h}$ (Figure 3 ). The results indicate that the most common secreted protease was metalloprotease. Protease activity in the presence of different inhibitors is comparable to previous reports about Serratia marcescens ATCC 25419. Similarly, the major protease identified as metalloprotease, this protease reached high levels at the end of the exponential phase after $18^{\text {th }} \mathrm{h}$ of growth. Like some extracellular proteases secreted by $S$. marcescens, this metalloprotease is synthesized during the late exponential phase $(16,29)$ Bacteria mostly secreted the serineand metalloproteinases, and to lesser extent, the cysteine proteases (16). In general, the major protease which had been detected in strains of Serratia was metalloprotease $(11,16)$.

Precipitation was an important method for purification of enzymes. One of the effective reagents for precipitation and concentration is ammonium sulfate. Proteins can be isolated with different concentrations of ammonium sulfate. In purification of protease from Serratia sp. ZF03, bacterial cultures were removed at the $48^{\text {th }} \mathrm{h}$ of growth. After centrifugation of cultures, different saturation levels $(50 \%, 60 \%, 67 \%, 70 \%$ and $80 \%)$ of ammonium sulfate were used for enzyme precipitation.

Enzymatic activity and SDS-PAGE analysis of precipitated supernatants confirmed that among those, $67 \%$ ammonium sulfate was the best. The result of SDS-PAGE showed that $50 \mathrm{kDa}$ metalloprotese of this fraction (67\% ammonium sulfate) was found to be major band. Similar report presented about purification of a $50308 \mathrm{Da}$ alkaline protease produced by $S$. marcescens S3-R1 from the Korean ginseng rhizosphere (30).

Metalloprotease from Serratia. sp. ZF03 was shown to be optimally active in the range of 50$55^{\circ} \mathrm{C}$ (Figure $5 \mathrm{~A}$ ). At $45^{\circ} \mathrm{C}$ retained $85 \%$ of its optimal activity. Protease activity declined abruptly to about $25 \%$ of the maximal value at $60^{\circ} \mathrm{C}$. The optimal temperatures of most bacterial metalloproteases are in the range of $45-60^{\circ} \mathrm{C}$. The metalloprotease activity at $\mathrm{pH}$ ranging from 5.0 to 9.0 increased steadily until achieving the maximum activity at approximately $\mathrm{pH}$ 9.0. This metalloprotease was optimally active at the $\mathrm{pH}$ range of 8.010.0 (with a maximum activity at $\mathrm{pH} 9.0$ ) (Figure 5B) similar to most alkaline metalloproteases (7, 12, 16, 31-35). For example, Metalloprotease produced by $S$. marcescens ATCC 25419 has $\mathrm{pH}$ profile with the maximum activity at $\mathrm{pH} 8.5$ and temperature profile (optimal activity at $45^{\circ} \mathrm{C}$ ) (16). Also, similar results were obtained from $S$. 
marcescens MH6 but the optimum temperature for metalloprotease was the range of $40-45^{\circ} \mathrm{C}$ and optimal pH was 8.0 (15). Other reports revealed metalloprotease from $S$. marcescens S3-R1 was optimally active at $40^{\circ} \mathrm{C}$ and $\mathrm{pH} 8.5$ (30). Comparison of results show that our metalloprotease had a higher optimal $\mathrm{pH}$ and temperature.

The use of inhibitors (Table 2) showed that EDTA inhibited significantly protease activity compared to PMSF and iodoacetamide. Also, 1, 10 phenanthroline, another inhibitor of metalloprotease, decreased enzyme activity. Iodoacetamide had not only inhibitory effect but also increased the proteolytic activity. Also, iodoacetamide didn't show any inhibition effect on zymogram gel. Considering that iodoacetamide is inhibitor of cysteine proteinases, This result suggests that no cysteine-protease was detected among the secreted enzymes in this strain. This data demonstrated that the metalloproteinases are the major proteases secreted by serratia sp. ZF03. Moreover, the results of zymogram analysis strongly showed the presence of metalloprotease in this strain.

In this study, the effect of metal ions and reagents on protease activity showed that $\mathrm{Co}^{2+}$, $\mathrm{Na}^{+}$marginally and reagents such as Iodoacetamide $0.1 \mathrm{mM}$ and $2 \%$ DMSO significantly increased metalloprotease activity. Enzyme behavior in the presence of metal ions and reagents is comparable to previous reports. It was shown that the activity of alkaline proteinases of $P$. aeruginosa and metalloprotease of Xenorhabdus were increased by $\mathrm{Co}^{2+}(36,37)$. Therefore, maybe $\mathrm{Co}^{2+}$ is able to reactivate the activity of protease after inhibition. Similar patterns of activation and stability by DMSO were observed for proteases from solvent-tolerant strains of $S$. marcescens MH6 and $P$. aeruginosa $(15,37)$. In the presence of ethanol, SDS detergent and $\mathrm{Zn}^{2+}$, the activity of metalloprotease decreased to $30 \%, 50 \%$ and $30.19 \%$ of its initial activity, whereas the addition of $\mathrm{Ba}^{2+}$ and $\mathrm{K}^{+}$ions and $1 \mathrm{mM}$ PMSF had no considerable effect on protease activity. $\mathrm{Fe}^{2+}, \mathrm{Fe}^{3+}$ and $\mathrm{Mn}^{2+}$ ions and 2 mM PMSF partially inhibited the activity of protease. Protease activity was inhibited by $\mathrm{Zn}^{2+}$, like that of metalloprotease reported from Serratia marcescens MH6. In contrast, The activity of the protease from strain ATCC 25419 increased in the presence of $\mathrm{Zn}^{2+}$ (16). This activation/inactivation by $\mathrm{Zn}^{2+}$ may be due to special structure in the catalytic site. $1 \%$ SDS detergent inhibited strongly the activity of MH6 protease whereas relative activity of our metalloprotease in presence of $5 \%$ SDS retained $50 \%$ of initial activity which suggested that cationic residues of the protease from S. marcescens MH6 was more than that of protease produced by ZF03 strain (15). Reagents like DMSO solvent and metal ions such as $\mathrm{Co}^{2+}, \mathrm{Na}^{+}$, $\mathrm{Ba}^{2+}, \mathrm{Mn}^{2+}, \mathrm{K}^{+}$may protect the protease conformation against environmental changes. Therefore protease can be stable and active at high temperatures in the presence of reagents. In thermoinactivation process, protease activity increased abruptly after $1 \mathrm{~min}$ of incubation at $40^{\circ} \mathrm{C}$ then it lost activity, it reached $98 \%$ of its initial activity after $10 \mathrm{~min}$ of incubation. This activation was probably due to the induction of flexibility in its relatively rigid structure of protease. Protease retained approximately $90 \%$ and $96 \%$ of its activity after 30 and $60 \mathrm{~min}$ respectively at $40^{\circ} \mathrm{C}$, whereas $24 \%$ of enzyme activity was conserved, when incubated at $50^{\circ} \mathrm{C}$ after $60 \mathrm{~min}$ (Figure 5C). Such thermal stability was observed about metalloprotease of $S$. marcescens $\mathrm{S} 3-\mathrm{R} 1$ at $40^{\circ} \mathrm{C}$ (30). Considering stability of protease at $40^{\circ} \mathrm{C}$, protease can be resistant and active in physiological and biochemical conditions in the human body.

In conclusion, the above results show that the protease investigated in this study, is an alkaline e. metalloproteas. Previous studies have shown that metalloproteases isolated from Serratia strains have anti-inflammatory effects and thus therapeutic properties $(12,19)$. Proteolytic enzymes that catalyze the hydrolysis of peptide bonds are present in all organisms and are involved in a large variety of physiological and biochemical functions. Most therapeutic enzymes are extracted from animals and microorganisms (10). Consequently, with respect to the high level of metalloprotease being produced by the Serratia. sp. ZF03 strain, and its strong proteolytic properties, the metalloprotease identified in this study can be a potential candidate for use in medicine and the pharmaceutical industries. Due to the important role of this metalloprotease, further enzymatic studies, structural analysis, formulation and immobilization of enzyme can be carried out in order to understand the mechanism of its activity and industrial applications. 


\section{Acknowledgements}

There is no acknowledgment.

\section{Authors' Contribution}

Salari N, performed her thesis. Dr, Hasannia supervised in this research. Dr. Sajedi and Dr. Akbari were thesis advisors.

\section{Funding/Support}

Financial support of this work was provided by the National Institute of Genetic Engineering and Biotechnology and Research Council of the University of Guilan.

\section{References}

1. Viswanathaswamy AH, Patil PA. Effect of Some Clinically Used Proteolytic Enzymes on Inflammation in Rats. Indian J Pharm. Sci. 2008;70(1):114117.doi:10.4103/0250-474X.40347

2. Aehle W. Enzymes in Industry: Production and Applications. 3th ed. Wiley-Vch Verlag GmbH \& Co. KGaA. Weinheim, Germany. 2007. PP. 314-320.

3. Basu B, Apte SK. A novel serralysin metalloprotease from Deinococcus radiodurans. Biochim Biophys Acta. 2008;1784(9):1256-1264.doi:10.1016/j.bbapap.2008.05.009

4. Baumann U. Serralysin and related enzymes. In Barrett AJ, Rawlings ND, Woessner JF, Handbook of Proteolytic Enzymes. Elsevier Academic Press. San diego: California; 2004. PP. 579581.doi:10.1016/B978-0-12-079611-3.50160-9

5. Hase CC, Fincelstein RA. Bacterial Extracellular ZincContaining Metalloproteases. Microbioll Rev. 1993;57(4):823-837.doi:10.1002/9780470508169.ch29

6. Mastrolorenzo A, Supuran CT. Botulinus Toxin, Tetanus Toxin, and Anthrax Lethal Factor Inhibitors. In Supuran CT, Winum JY, editors. Drug design of zinc-enzyme inhibitors: functional, structural, and disease applications. John Wiley \& Sons. Inc. Hoboken: New Jersey; 2009; PP. 705-717.

7. Wu JW, Chen XL. Extracellular metalloproteases from bacteria. Appl Microbiol Biotechnol. 2011;92:253262.doi:10.1007/s00253-011-3532-8

8. Gupta R, Beg QK, Lorenz P. Bacterial alkaline proteases: molecular approaches and industrial applications. Appl. Microbiol Biotechnol. 2002;59(1):1532.10.1007/s00253-002-0975-y

9. Gupta R, Beg QK, Khan S, Chauhan B. An overview on fermentation, downstream processing and properties of microbial alkaline proteases. Appl Microbiol Biotechnol. 2002;60:381-395.doi:10.1007/s00253-0021142-1

10. Gomis-Rüth FX. Structural Aspects of the Metzincin Clan of Metalloendopeptidases. Mol Biotechnol.
2003;24(2):157-202.

11. Jayaratne P. Major metalloprotease gene of Serratia marcescens is conserved and provides a molecular typing method to differentiate clinical isolates. $J$ Microbiol Methods. 1996;26(3):261-269.doi:10.1007/s00253002-1142-1

12. Salmone PR, Wodzinski RJ. Production, purification and characterization of a 50-kDa extracellular metalloproteases from Serratia marcescens. Appl Microbiol Biotechnol. 1997;48(3):317-324.doi:10.1007/s002530051056

13. Doerr M, Traub WH. Purification and characterization of two Serratia marcescens proteases. Zentralbl Bakteriol Mikrobiol Hyg [A]. 1984;257(1):6-19.

14. Matsumoto K, Maeda H, Takata K, Kamata R, Okamura R. Purification and Characterization of Four Proteases from a Clinical Isolate of Serratia marcescens kums 3958. J Bacteriol. 1984;157(1):225-232.

15. Wan MH, Wu B, Ren W, He B. Screening, Characterization, and Cloning of a Solvent-Tolerant Protease from Serratia marcescens MH6. J Microbiol Biotechnol. 2010;20(5):881888.from:http://dx.doi.org/10.4014/jmb.0910.10038

16. Romero FJ, Garcia LA, Salas JA, Diaz M, Quiros LM. Production, purification and partial characterization of two extracellular proteases from Serratia marcescens grown in whey. Process Biochem. 2001;36(6):507-515. doi:10.1016/S0032-9592(00)00221-1

17. Redfern RS. Pain relief, Inflammation relief and clear arteries. Naturally healthy publications. United Kingdom; 2004. PP. 14-23.

18. Kee WH, Tan SL, Lee V, Salmon YM. The treatment of breast engorgement with Serrapeptase (Danzen): a randomized double-blind controlled trial. Singapore Med J. 1989;30(1):48-54.

19. Al-Khateeb TH, Nusair Y. Effect of the proteolytic enzyme serrapeptase on swelling, pain and trismus after surgical extraction of mandibular third molars. Int $J$ Oral Maxillofac Surg. 2008;37(3):264-268. doi: http://dx.doi.org/10.1016/j.ijom.2007.11.011

20. Nakahama K, Yoshimura K, Marumoto R, Kikuchi M, Lee IS, Hase T, et al. Cloning and sequencing of Serratia protease gene. Nucleic Acids Res. 1986;14(14):5843-5855.doi: 10.1093/nar/14.14.5843

21. Nakamura S, Hashimoto Y, Mikami M, Yamanaka E, Soma $\mathrm{T}$, Hino M, et al. Effect of the proteolytic enzyme serrapeptase in patients with chronic airway disease. Respirology. 2003;8(3):316-320.10.1046/j.1440-1843.2003.00482.x

22. Mansfeld. J. Metalloproteases. In Polaina J, MacCabe AP, editors. Industrial Enzymes: Structure, Function and Applications. Springer. Dordrecht: The Netherlands; 2007. PP. 221-223. doi:10.1016/j.biortech.2010.07.032

23. Zakeri F, Noghabi KA, Sadeghizadeh M, Kardan MR, Masoomi F, Farshidpour MR, et al. Serratia sp. ZF03: An efficient radium biosorbent isolated from hot-spring waters in high background radiation areas. Bioresour Technol. 2010;101(23):9163-9170.doi:10.1016/0003- 
2697(76)90527-3

24. Bradford MM. A rapid and sensitive method for quantitation of microgram quantities of protein utilizing the principle of protein-dye binding. Anal Biochem. 1976;72:248-254.doi:10.1038/227680a0

25. Laemmli UK. Cleavage of structural proteins during the assembly of the head of bacteriophage T4. Nature 1970;227:680-685.doi:10.1038/227680a0

26. Britton HTS, Robinson RA. Universal buffer solutions and the dissociation constant of veronal. J Chem Soc. 1931;1456-1462.doi:10.1039/JR9310001456

27. Braunagel SC, Benedik MJ. The metalloprotease gene of Serratia marcescens strain SM6. Mol Gen Genet. 1990; 222(2-3):446-451.doi:10.1007/BF00633854

28. Rao M, AparnamTE , Ghatge MN, Deshpand V. Molecular and Biotechnological Aspects of Microbial Proteases. Microbiol Mol Biol Rev. 1998;62(3):597635.

29. Letoffe S, Delepelaire PH, Wandersman C. Cloning and Expression in Escherichia coli of the Serratia marcescens Metalloprotease Gene: Secretion of the Protease from E. coli in the Presence of the Erwinia chrysanthemi Protease Secretion Functions. $J$ Bacteriol. 1991;173(7):2160-2166.

30. Nam MS, Whang KS, Choi SH, Bae HCh, Kimd YK, Parke YW. Purification, characterization, and properties of an alkaline protease produced by Serratia marcescens S3-R1 inhabiting Korean ginseng rhizosphere, J Sci Food Agric. 2013; 93: 38763882.10.1002/jsfa.6363

31. Aiyappa PS, Harris JO. The extracellular metallopro- tease of Serratia marcescens: Purification and characterization. Mol Cell Biochem. 1976;13(2):95100.doi:10.1007/BF01837059

32. Amoozegar MA, Fatemi AZ, Karbalaei-Heidari HR, Razavi MR. Production of an extracellular alkaline metalloprotease from a newly isolated, moderately halophile, Salinivibrio sp. strain AF-2004. Microbiol Res. 2007; 162(4):369377.doi:10.1016/j.micres.2006.02.007

33. Bersanetti PA, Park HY, Bae KS, Son KH, Shin DH. Characterization of arazyme, an exocellular metalloprotease isolated from Serratia proteamaculans culture medium. Appl Microbiol Biotechnol. 2005; 67(6):209214.doi:10.1016/j.enzmictec.2005.01.041

34. Decedue CJ, Broussard EA, Larson AD, Braymer HD. Purification and characterization of the extracellular proteinase of Serratia marcescens. Biochim Biophys Acta. 1979;569(2):293-301.

35. Maeda H, Morihara K. Serralysin and related bacterial proteinases. Meth Enzymol. 1995;248:395413.doi:10.1016/0076-6879(95)48026-9

36. Massaoud MK, Marokházi J, Venekei I. Enzymatic characterization of a serralysin-like metalloprotease from the entomopathogen bacterium, Xenorhabdus. Biochim Biophys Acta. 2011;1814(10):13331339.doi:10.1016/j.bbapap.2011.05.008

37. Morihara K, Tsuzuki H, Oka T. On the specificity of Pseudomonas aeruginosa alkaline proteinase with synthetic substrates. Biochim Biophys Acta. 1973; 309(2):414-429.doi:10.1016/0005-2744(73)90040-5 